\title{
Lubou Kozik
}

Białoruski Uniwersytet Państwowy

\section{Białoruska historiografia Wielkiego Księstwa Litewskiego po 1991 roku}

\begin{abstract}
Zarys treści
W czasach sowieckich istnienie Wielkiego Księstwa Litewskiego uznawano za okupację Białorusi, co wraz z ówczesną teorią narodzin narodu staroruskiego dawało wsparcie dla przyłączenia ziem białoruskich do Rosji. Na początku lat 90. w niepodległej Białorusi powstała z kolei „narodowo-państwowa" koncepcja historii, której przedstawiciele uznawali Wielkie Księstwo Litewskie za państwo białorusko-litewskie i preferowali historię polityczną. Kolejne przemiany nastąpiły w połowie lat 90., kiedy to jedni powracali do koncepcji sowieckich, inni pozostawali na pozycjach narodowych. Różnicę tę dobrze widać w ocenach powstania Wielkiego Księstwa Litewskiego, zawierania unii oraz polityki zewnętrznej (zwłaszcza wobec Moskwy). W artykule wskazano najważniejsze kierunki badań i główne edycje źródłowe do dziejów Wielkiego Księstwa Litewskiego.
\end{abstract}

\begin{abstract}
During Soviet times the existence of the Grand Duchy of Lithuania was considered an occupation of Belarus. Together with the theory about the origins of the old Russian [sic!] nation it supported the unification of the Belarusian territories with Russia. At the beginning of the 1990s in independent Belarus the so-called "national state" conception of history was developed; its adherents considered the Grand Duchy of Lithuania a Belarusian-Lithuanian state and preferred political history. The next changes occurred in the mid-1990s, when some returned to historical views from Soviet times, others remained on the national historical positions. It is apparent in the evaluations of the founding of the Grand Duchy of Lithuania, the unions, and the foreign policy (especially towards Moscow). The article points out to the main directions in research and to major editions of sources to the history of the Grand Duchy of Lithuania.
\end{abstract}

Słowa kluczowe: Wielkie Księstwo Litewskie, historiografia białoruska, źródła

Key words: Grand Duchy of Lithuania, Belarusian historiography, sources

Powstanie niepodległej Republiki Białoruś w 1991 r. wymagało ideologicznego uzasadnienia, które nawiązywałoby nie tylko do radzieckiej przeszłości. Jeszcze w końcu lat 80. XX w. część badaczy oraz działaczy narodowych upatrywała 
pierwsze przejawy państwowości białoruskiej w księstwach połockim i turowskim, a dla późniejszego okresu w Wielkim Księstwie Litewskim, które postrzegano jako pierwsze potężne państwo białoruskie. Takie podejście do historii nie było nowe. Podobne koncepcje były formułowane przez działaczy narodowych jeszcze w końcu XIX i na początku XX w., kiedy trwała walka o powstanie państwa białoruskiego. Poniżej rozpatrzymy nastawienie historyków do Wielkiego Księstwa Litewskiego w XX i na początku XXI w. i wskażemy cechy charakterystyczne dla współczesnej historiografii białoruskiej.

Pierwsze prace $\mathrm{z}$ historii Białorusi, $\mathrm{w}$ których przedstawiono jej dzieje w obrębie Wielkiego Księstwa Litewskiego, zostały napisane przez Wacława Łastouskiego ${ }^{1}$, Usiewałada Ignatouskiego ${ }^{2}$, Mitrafana Dounar-Zapolskiego ${ }^{3}$, Uładzimira Piczetę ${ }^{4}$. W ich tekstach podkreślano, że Wielkie Księstwo Litewskie było państwem litewsko-białoruskim lub litewsko-ruskim, w skład którego ziemie białoruskie weszły dobrowolnie. Ten fakt badacze oceniali jako pozytywny moment w historii Białorusinów, a sam okres istnienia tego państwa często określali jako „złoty wiek” w historii Białorusi. Historycy zwracali uwagę na to, że wejście ziem białoruskich w skład Wielkiego Księstwa Litewskiego wiązało je z cywilizacją zachodnią. Opisując stosunki WKL z Rosją, badacze podkreślali częste konflikty między państwami, zaznaczając, że „wojska moskiewskie” niszczyły „tereny białoruskie”, bronione przez wojska „litewsko-białoruskie”.

Kiedy w latach 30. XX w. rząd sowiecki podjął walkę z tzw. narodową demokracją, ocena historii Wielkiego Księstwa Litewskiego zmieniła się diametralnie. W 1934 r. w ZSRR i BSRR w naukach historycznych nastąpiło przejście do metodologii marksistowsko-leninowskiej, co doprowadziło do powstania nowej, radzieckiej koncepcji historii tego państwa. Uznano, że powstało ono wskutek podboju ziem białoruskich przez feudałów litewskich, a sami Białorusini byli w nim prześladowani. W obronie ich interesów stawała Rosja, która jednocześnie pragnęła włączyć te ziemie w swoje granice. W oficjalnej historiografii Państwo Moskiewskie/Rosja carska występowały nie jako zaborca, ale jako „mniejsze zło”. Równocześnie kreowano wizerunek państwa moskiewskiego jako jedynego centrum jednoczenia ziem ruskich. W efekcie, od 1954 r. podbój ziem białoruskich przez państwo moskiewskie zaczęto oceniać $\mathrm{w}$ historiografii białoruskiej jako

${ }^{1}$ В. Ластоўскі, Кароткая гісторыя Беларусі, Вільня 1910 (wyd. 2 - Мінск 1993).

2 У. Ігнатоўскі, Кароткі нарыс гісторы Беларусі, Мінск 1992 (wуd. 5 - Мінск 1991).

${ }_{3}^{3}$ М. Доўнар-Запольскі, Асновы дзяржаўнасиі Беларусі, Гродна 1919.

4 У. Пічэта, Гісторыя Беларусі, t. 1, Масква-Ленінград 1924 (wyd. 2 - Мінск 2005); В. Пичета, История белорусского народа, Минск 2003.

${ }^{5} \mathrm{Na}$ ten temat zob. zwł.: P. Лінднер, Гісторыкі і ўлада. Нацыятворчы праиэс і гістарычная палітыка у Беларусі ХIX-XX ст., Мінск 2005, s. 85-88, 252-259; H. Sahanowicz, Wielkie Księstwo Litewskie jako zwierciadło białoruskiej historiografi, w: A Book of the Grand Duchy of Lithuапіа / Кніга Вялікага княства Літоўскага / Lietuvos Didžiosios Kunigaikštystès Knyga / Księga Wielkiego Księstwa Litewskiego, Sejny 2008, s. 245-247. 
zjawisko postępowe i pozytywne, mające na celu wyzwolenie narodów prześladowanych. Z niewielkimi zmianami koncepcja ta przetrwała w ZSRR i w BSRR do końca lat 80 . XX w. Próby niektórych naukowców białoruskich w II połowie lat 40. XX w., mające na celu stworzenie narodowej interpretacji historii Wielkiego Księstwa Litewskiego i odpowiednio Białorusi zostały poddane ostrej krytyce ze strony władz moskiewskich ${ }^{6}$. Po II wojnie światowej, historia narodowa była prezentowana w BSRR w ściśle ustalonej konwencji. Twierdzono, że okres istnienia Wielkiego Księstwa Litewskiego był najgorszym czasem w historii Białorusi, ponieważ białoruskie ziemie znajdowały się we władzy litewskich oraz polskich okupantów.

Na dodatek, obok wspomnianych idei w połowie lat 50. XX w. w ZSRR pojawiła się teoria powstania narodu staroruskiego i jego państwa - Rusi Kijowskiej. Stała się ona dodatkowym argumentem za przyłączeniem do Rosji ziem białoruskich, których ludność była prześladowana przez litewskich i polskich feudałów. Próby odejścia od oficjalnej wykładni historii przez niektórych historyków białoruskich w końcu lat $60 . \mathrm{XX}$ w. nie miały szans na powodzenie ${ }^{7}$. Od końca lat 60. XX w. w BSRR wzmacniała się presja ideologiczna na tych badaczy, którzy mieli wątpliwości co do słuszności oficjalnej sowieckiej wersji historii Wielkiego Księstwa Litewskiego. Tubą oficjalnej ideologii w BSRR stały się prace Łaurencja Abecedarskiego, który w 1968 r. w broszurze „W świetle niezaprzeczalnych faktów" "wystąpił z krytyką idei narodowodemokratycznych i stwierdził, że poprawna jest tylko oficjalna interpretacja głosząca, że dla Białorusinów Wielkie Księstwo Litewskie było państwem obcym.

Charakteryzując tematykę badań prowadzonych w „czasach radzieckich”, należy zauważyć, że historycy faktycznie nie zajmowali się polityczną historią Białorusi. Klasowe podejście do doboru tematów ograniczało badania dziejów państwa, prawa, szlachty jako stanu oraz religii, przez co przewagę zyskały badania procesów społeczno-ekonomicznych. Syntetyczną pracą z historii Białorusi, gdzie w pełnej mierze przedstawiono oficjalny punkt widzenia w tym czasie była „Historia Białoruskiej SRR" w 5 tomach, wydana w $1972 \mathrm{r}^{9}$

W BSRR przedstawiona wyżej koncepcja historii Wielkiego Księstwa Litewskiego dominowała do końca lat 80 . XX w. W pewnym sensie odpowiedzią na nią była książka Mikołaja Jermałowicza „Śladem jednego mitu”10, w której pokazano historię powstania Wielkiego Księstwa Litewskiego, pociągającą z narodowego punktu widzenia, ale słabo uargumentowaną naukowo. Autor odrzucał radziecką

\footnotetext{
${ }^{6}$ H. Sahanowicz, Wielkie Księstwo Litewskie..., s. 249-251.

${ }^{7}$ Ibidem, s. 253-255.

8 Л. Абецэдарскі, У святле неабвержаных фактаў, Мінск 1969.

${ }^{9}$ Гісторыя Беларускай ССР: у 5 тамах, t. 1: Периабытнаабичынны тад на тэрыторыі Беларусі. Эпоха феадалізму, red. І. Ігнаценка, Мінск 1972.

${ }^{10}$ М. Ермаловіч, Па слядах аднаго мібба, Мінск 1989.
} 
wersję o podboju Rusi przez książąt litewskich i dowodził, że utworzenie państwa miało miejsce po tym, jak bojarzy z Nowogródka podporządkowali sobie Litwę przy pomocy (wynajętego w tym celu) księcia Mendoga. Dodatkowo, Jermałowicz zlokalizował dawną Litwę na obszarze dzisiejszej Białorusi (pomiędzy ziemią Połocką, Turowską, Pińską i Nowogródzką). Tym samym w końcu lat 80. XX w. pojawiła się nowa teoria o białoruskich początkach Wielkiego Księstwa Litewskiego.

Ogłoszenie niepodległości Białorusi wiąże się z powstawaniem nowej koncepcji historii narodowej w latach 1991-1993. Otrzymała ona nazwę „narodowo-państwowej", bo dawała priorytet wartościom narodowym oraz deklarowała deideologizację i depolityzację historii ${ }^{11}$. W I połowie lat 90 . XX w. w rozwoju historiografii białoruskiej charakterystyczne były takie cechy jak swoboda w wyborze tematu badań, metodologii, kształtowanie nowych celów naukowych. W owym czasie rosła liczba wydawnictw na tematy historyczne (większość z nich miała charakter popularnonaukowy), pojawiło się więcej możliwości wydawania prac (chociaż w niewielkim nakładzie). Dostępne stały się prace badaczy zagranicznych i emigracyjnych, które wcześniej były zakazane. Pojawiła się możliwość współpracy z kolegami z zagranicy, organizacji z nimi wspólnych konferencji i badań.

Wśród nowych pozycji znalazła się synteza dziejów Białorusi „Szkice z historii Białorusi" w 2 tomach ${ }^{12}$. Poczesne miejsce zajmowała w niej historia Wielkiego Księstwa Litewskiego. Trzeba zauważyć, że w białoruskiej historiografii historię tego państwa historycy praktycznie zaczynali „od zera”, bo nie można powiedzieć o ciągłości w badaniach, np. w zakresie historii politycznej. W I połowie lat 90 . $\mathrm{XX}$ w. oceny badaczy białoruskich były bardzo bliskie ocenom historyków $\mathrm{z}$ lat 20. XX w., których prace były ponownie wydawane. Nie oznaczało to jednak, że ich koncepcje były przejmowane w całości. Współcześni historycy zwrócili uwage na dobrowolny charakter utworzenia państwa białorusko-litewskiego Wielkiego Księstwa Litewskiego (w latach 20. XX w. nazywano je litewsko-białoruskim). Wśród jego głównych wrogów wskazano państwo moskiewskie, co świadczyło o przekształceniu wizji Rosji ze „starszego (wielkiego) brata” w agresywnego sąsiada ${ }^{13}$. Jeszcze jednym elementem $\mathrm{w}$ postrzeganiu i opisywaniu Wielkiego Księstwa Litewskiego stało się podkreślanie jego europejskiego charakteru oraz przynależności do kręgu cywilizacji zachodniej.

Połowa lat 90. XX w. okazała się w pewnym sensie przełomem w rozwoju historiografii białoruskiej. Było to związane z przemianami politycznymi w państwie i wyraźnie prorosyjską postawą Mińska. Od tej pory w historiografii obserwuje się

${ }^{11}$ М. Біч, Аб нацыянальнай каниэпцыьі гісторысі і гістарычнай адукащы уі у Рэспубліцы Беларусь, „Беларускі гістарычны часопіс” 1993, nr 1, s. 15-24.

${ }^{12}$ Нарысы гісторыі Беларусі, сz. 1, red. М. Касцюк, Мінск 1994.

${ }^{13}$ Г. Сагановіч, Бітва пад Оршай 1514 г.: канфлікт інтэрпрэтащый у беларускім і расійскім „месиах памяці 
powrót do teorii jedynego narodu staroruskiego ${ }^{14}$ oraz do negatywnej oceny okresu funkcjonowania ziem białoruskich w składzie Wielkiego Księstwa Litewskiego i Rzeczypospolitej. Część historyków, przeważnie starszych wiekiem, spróbowała „powrócić" do koncepcji, która panowała w czasach sowieckich pod postacią idei słowiańskiej jedności narodów białoruskiego, rosyjskiego i ukraińskiego. Ostatecznie doprowadziło to do podziału badaczy na dwie grupy - zorientowaną narodowo (prozachodnią) i grupę oficjalną (prorosyjską lub antyzachodnią).

Lata 90. XX w. odznaczyły się wzrostem zainteresowania historią polityczną Wielkiego Księstwa Litewskiego. W tym - ważnymi problemami powstania i kształtowania państwa. Wyżej wspomniałam już o pracy M. Jermałowicza, do której specjaliści podchodzą bardzo krytycznie ${ }^{15}$. Większość badaczy białoruskich uważa, że główną przyczyną powstania Wielkiego Księstwa Litewskiego była obustronna gotowość do współpracy litewsko-białoruskiej, która przynosiła korzyści obu stronom. Ekspansja Litwinów odpowiadała interesom białoruskim, bo dzięki niej Białorusini bronili się przed zagrożeniami zewnętrznymi, wykorzystując wojowników litewskich. Od końca XII i przez cały XIII w. Białorusini zawierali sojusze wojskowe z Litwinami, zapraszali do siebie litewskich książąt wraz $\mathrm{z}$ wojskiem albo wiązali ich ze sobą drogą ożenków, aby ci ich bronili i poszerzali terytoria białoruskich państw-miast. Po przybyciu do obcego kraju, Litwini całkowicie się asymilowali. Powstanie Wielkiego Księstwa Litewskiego zdaniem białoruskich badaczy było wynikiem pokojowego łączenia się terenów litewskich i białoruskich, a przyczyną jego powstania była wspólnota interesów ${ }^{16}$.

Wśród autorów, którzy zajmują się problemem powstania Wielkiego Księstwa Litewskiego, należy wymienić Wiaczasława Nasiewicza ${ }^{17}$ i Aliaksandra Kraucewicza $^{18}$. Obaj badacze reprezentują koncepcję narodową, ale w ich poglądach są pewne rozbieżności. Nasiewicz twierdzi, że na wczesnym etapie formowania państwa główny autorytet polityczny miała szlachta litewska, podczas gdy ziemie ruskie (białoruskie oraz ukraińskie) grały wiodącą rolę w rozwoju kulturalnym i społecznym kraju. Z kolei Kraucewicz uważa, że w Wielkim Księstwie Litewskim główną rolę polityczną grały właśnie ziemie białoruskie (ruscy bojarzy) ${ }^{19}$.

${ }^{14}$ Гісторыя Беларусі: вучэбны дапаможнік, сz. 1, red. Я. Новік, Г. Марцуль, Мінск 1998; Я. Трещенок, История Беларуси: учебное пособие, cz. 1, Могилев 2003 i in.

${ }^{15}$ M. Jermałowicz wydał jeszcze kilka książek na temat Wielkiego Księstwa Litewskiego: М. Ермаловіч, Старажытная Беларусь: Віленскі перыяд: гістарычны нарыс, Мінск 1994; idem, Беларуская дзяржава Вялікае княства Літоускае, Мінск 2000 i in.

${ }^{16}$ Гісторыя Беларусі, t. 2, red. М. Касцюк, Мінск 2008. O różnicach w ocenach historyków białoruskich oraz litewskich zob.: R. Kamuntavičius, Powstanie Wielkiego Księstwa Litewskiego według Litwinów i Białorusinów, w: A Book of the Grand Duchy of Lithuania..., s. 47-71.

17 В. Насевіч, Пачаткі Вялікага княства Літоўскага: Падзеі і асобы, Мінск 1993.

18 А. Краўцэвіч, Стварэнне Вялікага княства Літоўскага, Мінск 1998.

${ }^{19}$ Dyskusja tych badaczy toczyła się m.in. na łamach czasopisma „Беларускі гістарычны агляд” 1998 , t. 5, nr 1, s. 210-226; nr 2, s. 448-456. 
Co się tyczy dziejów politycznego rozwoju Wielkiego Księstwa Litewskiego od XIII do połowy XVI w., badacze zwracają uwagę przede wszystkim na specyfikę sprawowania władzy przez wielkiego księcia litewskiego ${ }^{20}$, organizację pracy kancelarii Księstwa ${ }^{21}$, walkę polityczną 22 , funkcjonowanie miast ${ }^{23}$ itp.

Ważnym wydarzeniem w historii Wielkiego Księstwa Litewskiego było podpisanie aktu unii lubelskiej. Na początku lat 90 . XX w. radziecka teza o zmowie feudałów polsko-litewskich przeciwko narodom białoruskiemu i ukraińskiemu została odrzucona. Dziś unię lubelską traktuje się jako historyczną konieczność w skomplikowanych warunkach wojny o Inflanty ${ }^{24}$.

W historiografii niepodległej Białorusi zwrócono uwagę na dobrowolny charakter zawarcia unii polsko-litewskiej, chociaż podkreślano, że po podpisaniu aktu zjednoczeniowego w Lublinie w 1569 r. Wielkie Księstwo Litewskie znalazło się w gorszym położeniu niż Korona. Chyba po raz pierwszy w białoruskiej literaturze przedmiotu prawno-ustrojowy kształt Rzeczypospolitej scharakteryzowano jako federację dwóch organizmów państwowych, państwo wielu narodów, w którym należne sobie miejsce zajęli także Białorusini. Konieczność zawarcia unii wyjaśniano przede wszystkim potrzebą obrony przed agresją moskiewską. Badacze zaznaczają, że z jednej strony unia, podpisana w warunkach trudnej sytuacji wojskowej i politycznej kraju, uwolniła Wielkie Księstwo Litewskie od zagrożenia najazdami Tatarów krymskich i wojny z Turcją, doprowadziła do przełomu w wojnie $\mathrm{z}$ Rosją, a $\mathrm{z}$ drugiej strony - strata południowych i zachodnich ziem ograniczała polityczne i społeczno-ekonomiczne możliwości państwa,

${ }^{20}$ И. Уваров, Развитие институтов государственной власти в Великом княжестве Литовском в $X V-X V I$ вв., „Веснік Мазырскага дзяржаўнага ўніверсітэта імя І.П. Шамякіна” 2009, nr 3, s. 28-31.

${ }^{21}$ А. Груша, Канцылярыя Вялікага княства Літоўскага 40-х гадой XV - першай паловы XVI cm., Мінск 2006; ideт, Документальная письменность Великого княжества Литовского (конеи XIV - первая треть XVI в.), Минск 2015.

22 А. Краўцэвіч, Гісторыя Вялікага княства Літоускага, 1248-1377, Гародня-Уроцлаў 2015; В. Насевіч, Беларусы: станаўленне этнасу і нацыянальная ідэя, Смаленск 2015.

${ }^{23}$ Р. Баравы, Атрыманьне магдэбурскага права Берасьцем і палітычная барацьба у Вялікім Княстве Літоўскім на мяжы XIV-XV ст., „Беларускі гістарычны агляд” 1994, t. 1, nr 1, s. 38-53; С. Стрэнкоўскі, Вольнасиі і прывілеі гарадоў заходняй часткі Вялікага княства Літоўскага, Мінск 1997; В. Варонін, Арганізащыл гарадской улады ў Полацку ад канца $X I V$ да сярэдзіны XVI cm., „Studia Historica Europae Orientalis. Исследования по истории Восточной Европы” 2010, t. 3, s. 124-134; Магдэбургскае права на Беларусі, red. У. Хоміч, Т. Доўнар, І. Юхо, Мінск 1999; Н. Місарэвіч, Магдэбургскае права на Беларусі, Гродна 2008; Прыватнаўласніцкія гарады ВКЛ: лёс праз стагоддзі, red. С. Клімаў, 3. Яцкевіч, А. Блінц, Мінск 2014 i in.

${ }^{24}$ Zob. nр.: А. Янушкевіч, Унія з Каронай ва ўнутранай палітыщы ВКЛ перад Люблінскім соймам 1569 г., „Беларускі гістарычны агляд” 2003, t. 10, nr 1-2, s. 29-58; Вялікае княства Літоўскае. Энцыьлапедыя: у 2 тамах, t. 1, red. Г. Пашкоў, Мінск 2005, s. 18; Гісторыя Беларусі, t. 2, red. М. Касцюк, Мінск 2008, s. 457-479; H. Sahanowicz, O unii lubelskiej z perspektywy białoruskiej, w: Unia lubelska: dziedzictwo wielu narodów, red. A. Gil, Lublin 2010, s. 61-78. 
co potencjalnie mogło prowadzić do podporządkowywania Wielkiego Księstwa Litewskiego Koronie Polskiej, co wówczas jednak nie nastąpiło.

Opisując polityczny rozwój Wielkiego Księstwa Litewskiego w składzie Rzeczypospolitej Obojga Narodów, historycy skupiają uwagę na udziale szlachty w życiu politycznym i społecznym ${ }^{25}$, funkcjonowaniu instytucji władzy w poszczególnych województwach i ziemiach ${ }^{26}$, walce ugrupowań magnackich ${ }^{27}$, rozbiorach Rzeczypospolitej $^{28}$, powstaniu pod wodzą Tadeusza Kościuszki ${ }^{29}$.

Do zagadnień słabo zbadanych przez białoruskich naukowców można zaliczyć: udział ziem „ruskich” w umocnieniu i obronie Wielkiego Księstwa Litewskiego,

${ }^{25}$ Zob. m.in. П. Лойка, Шляхта беларускіх земляў у грамадска-палітычным жыциі Рэчы Паспалітай другой паловы XVI - першай трэиі XVII cm., Мінск 2002; idem, Афармленне шляхецкага саслоўя у Вялікім княстве Літоўскім, „Працы гістарычнага факультэта БДУ” 2010, t. 5, s. 102-115; У. Падалінскі, Шляхта ВКЛ і вальны сойм Рэчы Паспалітай 1570 года, „Беларускі гістарычны часопіс” 2004, nr 6, s. 50-54; idem, Прадстаўніцтва ВКЛ на вальных соймах Рэчы Паспалітай (1569-1600 гг.). Да пытання рэгіянальных асаблівасияў, w: Канструкцыя і дэканструкцыя Вялікага княства Літоўскага, red. Н. Сліж, Мінск 2007, s. 57-67; idem, Грамадская думка шляхты Вялікага Княства Літоўскага каниа XVI cm. (на прыєкадзе соймавай кампаніi Рэчь Паспалітай 1595 г.), „Спадчына” 2008, nr 1, s. 12-24; idem, Стаўленне да вайны у грамадскай думцы шляхты Вялікага Княства Літоўскага $\check{y}$ 1570-1580-я г2., „Studia Historica Europae Orientalis: Исследования по истории Восточной Европы” 2008, t. 1, s. 84-98; idem, Ухваленне падаткаў на вальных соймах Рэчы Паспалітай як фактар палітычнай барацьбы (1593-1598 г2.), „Сацыяльна-эканамічныя і прававыя даследаванні” 2009, nr 3, s. 157-176; idem, Стаўленне шляхты Вялікага Княства Літоўскага да інстылута вальнага сойма ў канцы XVI cm., „Беларускі гістарычны часопіс” 2012, nr 8, s. 15-24; idem, Галоўны з'езд Вялікага Княства Літоўскага: генезіс, функцыьі, гістарычнае развіциё, „Беларускі гістарычны часопіс” 2015, nr 1, s. 13-23.

${ }^{26}$ В. Варонін, Палітычны лад Полачкага ваяводства у першай палове XVI cm., „Беларускі гістарычны агляд” 1998, t. 5, nr 1, s. 27-66; idem, Друцкія князі XIV стагоддзя, „Беларускі гістарычны агляд” 2002, t. 9, nr 1-2, s. 3-29; idem, Старонка біяграфіi князя Андрэя Полацкага, „Гістарычны альманах” 2009, t. 15, s. 2-6; В. Галубовіч, Miscellanea Historica Polocensia. Даследаванні па гісторыь Полаччыны XII-XVII cmcm., Гродна 2914; idem, Полачкая иляхта у час праўлення дынастьі Вазаў: 1588-1668, Гродна 2015.

27 Zob. m.in. Г. Прыбытка, Баращьба магнацкіх груповак у другой палове XVII - пачатку XVIII cm., „Спадчына” 1995, nr 5, s. 32-90; idem, Барацьба магнаикіх груповак у XVIII cm., „Спадчына” 1996, nr 1, s. 80-150; А. Мацук, Барацьба магнацкіх груповак вакол Трыбунала Вялікага княства Літоўскага 1741 года, „Вестник Полоцкого государственного университета" 2009, nr 7, s. 22-31; idem, Барацьба магнацкіх груповаку ВКЛ (1717-1763), Мінск 2010; idem, Барацьба магнацкіх груповак за уррад падканилера ВКЛ у 1752 г., „Весці Нацыянальнай акадэміі навук” 2010, nr 1, s. 57-64; idem, Полацкае ваяводства ў XVIII cm.: ваявода, шляхеикая эліта, соймікі, Мінск 2014.

${ }^{28}$ Е. Анищенко, Сторона неприкаянная: книга об утрате нашей вольности: [о подчинении белорусских земель российскому господству накануне первого раздела Речи Посполитой в 1772 г.], Минск 2009; idem, Інкарпаращыя: Літоўская правінцыя ў падзелах Рэчы Паспалітай, Мінск 2013.

${ }^{29}$ У. Емяльянчык, Паланез для касінераў: 3 падзей паўстання 1794 г. пад кіраўніцтвам Т. Касиюшкі на Беларусі, Мінск 1994. 
przemiany w sytuacji politycznej państwa w końcu XV - połowie XVI w., wzrost wpływów białorusko-ukraińskiego możnowładztwa i formowanie stanu szlacheckiego, proces przekształcania struktury administracyjno-terenowej i sądoweje, politykę zagraniczną. Dla ostatniego z tych tematów ważnym czynnikiem jest wpływ ideologii na badania, zwłaszcza w odniesieniu do wojen z Państwem Moskiewskim.

W zakresie badań nad polityką zagraniczną Wielkiego Księstwa Litewskiego można skonstatować, że niektóre przedziały czasowe po prostu umykają. Najlepiej zbadane są wydarzenia XV-XVI w. Badacze zwracają uwagę na walkę z Krzyżakami, z Państwem Moskiewskim oraz z Tatarami ${ }^{31}$. Jeżeli mówimy o wschodniej polityce Wielkiego Księstwa Litewskiego w XVI w., to w pierwszej kolejności trzeba wymienić prace Andreja Januszkiewicza ${ }^{32}$ i śp. Wiktara Temuszawa ${ }^{33}$. Ale już polityka zagraniczna w XVII w. ucieka z pola widzenia uczonych. Po wydaniu w połowie lat 90. XX w. popularnonaukowej książki Hienadzia Sahanowicza „Nieznana wojna" ${ }^{4}$ na Białorusi ukazała się tylko jedna monografia o wojnach i polityce zagranicznej Wielkiego Księstwa Litewskiego w XVII w. ${ }^{35} \mathrm{~W}$ ostatnich

${ }^{30}$ Przeważnie prace regionalistyczne: В. Цішчанка, Аспекты адміністрацыйна-маёмаснай і судовай практыкі вялікіх князёу у Вялікім княстве Літоўскім (канеи, XV - першая трэць XVI cm.), „Studia Historica Europae Orientalis. Исследования по истории Восточной Европы” 2009, t. 2, s. 123-135; А. Шаланда, Земскі суд Гарадзенскага павета ў 1555-1564 г2., „Гарадзенскі палімпсест” 2009, s. 35-64; idem, Дарэформенны земскі суд Гарадзенскага павета у 1562-1564 г2., „Гарадзенскі палімпсест” 2011, s. 45-56; А. Радаман, Полацкі земскі суд у другой палове XVI - першай трэиі XVII cmcm., w: Гісторыя і археалогія Полаика i Полацкай зямлі, red. Т. Джумантаева, Полацк 2002, s. 216-277; idem, Арганізацыья і склад полацкага земскага суда ў другой палове XVI - першай трэці XVII cm., „Герольд - Litherland” 2011, nr 18, s. 21-36.

${ }^{31}$ Г. Сагановіч, „Русь” у вайне з Нямеикім ордэнам (канеи ХIII - пач. XV cm.), „Беларускі гістарычны агляд" 2001, t. 8, nr 1-2, s. 4-24; Р. Гагуа, Вялікая вайна Вялікага княства Літоускага і Каралеуствва Польскага з Тэўтонскім ордэнам у 1409-1411 г., „Гістарычны альманах" 2003, nr 8, s. 145-166; А. Любая, Татарский фактор во взаимоотношениях государств Восточной Европь в конце XV - первой трети XVI в., „Вышэйшая школа” 2008, nr 4, s. 28-32; В. Цемушаў, „Вайна падчас міру”. Першая памежная вайна ВКЛ з Масквою (1486-1494), „Беларускі гістарычны агляд” 2008, t. 15, nr 1-2, s. 5-48; idem, Первая московско-литовская пограничная война 1486-1494, Москва 2013.

32 А. Янушкевіч, Вялікае княства Літоўскае і Інфлянцкая вайна 1558-1570, Мінск 2007; idem, Ливонская война. Вильно против Москвы, 1558-1570, Москва 2013; ideт, Ливонская война 1558-1570 г2. и Великое княжество Литовское, Минск 2013, oraz jego liczne artykuły.

${ }^{33}$ В. Темушев, На восточной границе Великого княжества Литовского (середина XIV - первая половина XVI в.), Смоленск 2014.

${ }^{34}$ Г. Сагановіч, Невядомая вайна, 1654-1667, Мінск 1995.

${ }^{35}$ А. Катлярчук, У иеню Польшчы $і$ Расеі. Вялікае княства Літоўскае і Швецыя у часе еуррапейскага крызісу сярэдзіны XVII ст., Мінск 2009. Z artykułów na ten temat zob. np.: А. Катлярчук, Другая Паўночная вайна і апочняя шведская аперацыя ў ВКЛ: аблога Бераси, 1657 г. і спрэчка за места, „Беларускі гістарычны агляд” 2005, t. 12, nr 1-2, s. 35-60; Г. Сагановіч, ВКЛ і вайсковыя канфедэрацыі 1612-1614 2., „Беларускі гістарычны 
10-15 latach miały miejsce obrony prac doktorskich z historii polityki zagranicznej Wielkiego Księstwa Litewskiego, nadal jednak nie ma syntezy na ten temat (oprócz podręcznika akademickiego Uładzimira Snapkouskiego ${ }^{36}$ ). Poza tym, jak zaznaczają specjaliści, zbyt mała liczba edycji tekstów źródłowych ogranicza możliwość badań w tym zakresie.

Z dziejami polityki zagranicznej wiążą się badania historii wojen i wojskowości. Warto zatem zauważyć, że w ostatnim czasie na Białorusi ukazało się kilka rozpraw $\mathrm{z}$ historii militariów oraz tradycji rycerskich ${ }^{37}$. Natomiast $\mathrm{w}$ ostatnim czasie znacznie zmniejszyło się zainteresowanie badaczy problemami historii społeczno-ekonomicznej Wielkiego Księstwa Litewskiego. W znacznej mierze można to wytłumaczyć niechęcią, spowodowaną dominacją historii gospodarczej w czasach sowieckich, oraz fascynacją historią polityczną. Wśród specjalistów w tej dziedzinie wymienimy śp. Pawła Łojkę ${ }^{38}$, śp. Michaiła Spirydonowa ${ }^{39}$, Waliancina Gołubiewa $^{40} \mathrm{i}$ in. Co do syntez z historii chłopów, to warto wskazać „Historię chłopstwa Białorusi. Od dawnych czasów do 1861 r." ${ }^{11}$ (rękopis powstał jeszcze w latach 80. XX w.) oraz „Białorusini. Pochodzenie i rozwój etniczny”42. Wśród najgorzej zbadanych tematów wskazuje się zwykle problemy kształtowania i rozwoju elit społecznych Wielkiego Księstwa Litewskiego (bojarstwo, szlachta, kler), chociaż i tu w ostatnich latach widoczny jest postęp ${ }^{43}$.

агляд” 2008, t. 15, nr 1-2, s. 100-123; іdem, Вайна на полацка-віцебскім рубяжы ў 1632 1633 г. i „паўстанне” у Полацку, „Беларускі гістарычны агляд” 2011, t. 18, nr 1-2, s. 21-42; А. Дземідовіч, Узаемадачыненні Вялікага княства Літоўскага з Расійскай дзяржавай (першая трэць XVII cm.), „Веснік Беларускага дзяржаўнага ўніверсітэта”, ser. 3: „Гісторыя, філасофія, псіхалогія, паліталогія, эканоміка, права" 2008, nr 3, s. 3-7.

36 У. Снапкоўскі, Гісторыя знешняй палітыкі Беларусі, сz. 1, Мінск 2003.

${ }^{37}$ Zob. m.in. Г. Сагановіч, Войска Вялікага княства Літоўскага у XVI-XVII cт., Мінск 1994; Ю. Бохан, Узбраенне войска ВКЛ другой паловы XIV - канцза XVI cm., Мінск 2002; idem, Наёмнае войска у Вялікім княстве Літоўскім у XV-XVI ст., Мінск 2003; idem, Зброя Вялікага княства Літоўскага, 1385-1576, Мінск 2003; idem, Вайсковая справа у Вялікім княстве Літойскім у другой палове XIV - канщы XVI cm., Мінск 2008; idem, Турнірныя традыцы у у Вялікім княстве Літоўскім у XIV-XVI стагоддзях, Мінск 2008; idem, Ваяры Грунвальдскай бітвы, Мінск 2010.

38 П. Лойка, Прыватнаўласніикія сяляне Беларусі: Эвалюиьья феадальнай рэнты у другой палове XVI-XVIII cm., Мінск 1991.

${ }_{39}$ М. Спиридонов, Закрепощение крестьянства Беларуси (XV-XVI вв.), Минск 1993.

${ }^{40}$ В. Голубеў, Сялянскае землеўладанне і землекарыстанне на Беларусі XVI-XVIII cmcm., Мінск 1992; idem, Сялянская абшчына ў Беларусі XVI-XVIII cm., Мінск 2008.

${ }^{41}$ Гісторыя сялянства Беларусі: у 3 m., t. 1: Гісторыя сялянства Беларусі ад старажытнасиі да 1861 г., red. М. Касцюк, Мінск 1997.

42 Беларусы, t. 4: Вытокі і этнічнае развіцицё, red. В. Бандарчык, М. Піліпенко, І. Чаквін, Мінск 2001.

${ }^{43}$ Zob. m.in. В. Варонін, Князь Юрай Лынгвеневіч Мсиіслаўскі: гістарычны партрэт, Мінск 2010; Ю. Казаков, Самоидентификация шляхецкого сословия в ВКЛ в коние XV - начале XVII в., „Працы гістарычнага факультэта БДУ” 2010, t. 5, s. 278-286; А. Скеп’ян, Князі 
Natomiast daje się obecnie zauważyć wzrost zainteresowania historią religii. O ile do końca lat 80. religię badano przeważnie w celu poddania jej krytyce, o tyle w niepodległej Białorusi próbuje się pokazać jej miejsce i rolę w społeczeństwie. W ostatnim czasie ukazało się sporo artykułów o pozycji Cerkwi prawosławnej ${ }^{44}$ oraz wyznaniach reformowanych ${ }^{45} \mathrm{w}$ Wielkim Księstwie Litewskim. Na poglądy badaczy, którzy zajmują się tą problematyką, duży wpływ mają ich przekonania polityczne i religijne oraz tradycje historiografii sowieckiej. W znacznej mierze dotyczy to przedstawicieli Cerkwi prawosławnej. W związku z tym najbardziej ostre dyskusje toczą się wokół unii brzeskiej, którą tradycyjnie postrzegano jako zagrożenie dla prawosławnych Białorusinów ${ }^{46}$. Oceniając całościowo białoruską

слуцкія, Мінск 2013; Дз. Лісейчыкаў, Штодзённае жыцё унніяцякага парабіяльнага святара беларуска-літоўскіх зямель 1720-1839 г2., Мінск 2011; idem, Святар у беларускім соцыууме: прасапаграбія унніяцкага духавенства 1596-1839, Мінск 2015; А. Дзянісава, Манастырскае жыциё ў Турава-Пінскай епархіі ў XI-XVII cmст., w: Да сваёй гісторыі: Сярэднявечча і Ранні Новы час, red. В. Варонін, Смаленск 2013, s. 9-22; Магнацкі двор і сацыяльнае ўзаемадзеянне (XV-XVIII cmcm.), red. А. Янушкевіч, Мінск 2014.

${ }^{44}$ Zob. m.in. A. Вернікоўская, Супраціўленне праваслаўных Полацкай епархіі ўвядзенню унніі і забойства Язабата Куниэвіча, „Беларускі гістарычны агляд” 2001, t. 8, nr 1-2, s. 25-54; Р. Баравы, Хрысціянізацыл тэрыторы Тураўскай і Полацкай епархіі X-XIV cm., „Беларускі гістарычны агляд” 2003, t. 10, nr 1-2, s. 3-28; В. Варонін, Праваслаўныя иэрквы і манастыры горада Полацка (да 1582 г.), „Studia Historica Europae Orientalis. Исследования по истории Восточной Европы” 2009, t. 2, s. 152-174; О. Голубев, Православная церковь в Великом княжестве Литовском в первой половине XIV в., „Вышэйшая школа” 2010, nr 4, s. 55-59; А. Дзянісава, Распаўсюджванне хрысиіянства $і$ фарміраванне изаркойнай структуры $\check{y}$ межах Тураўскай зямлі у XI - першай палове XIII cm., „Studia Historica Europae Orientalis. Исследования по истории Восточной Европы” 2012, t. 5, s. 25-40; К. Апанович, Специфика межконфессиональных отночений в Речи Посполитой в конце XVI - первой трети XVII в., w: Религия и общество - 7, red. В.В. Старостенко, О.В. Дьяченко, Могилев 2012, s. 12-14; еаdет, Политика правительства Речи Посполитой по отночению к православной церкви в конце XVI - первой трети XVII в., „Научные труды Республиканского института высшей школы" 2012, t. 12, cz. 1, s. 3-11.

45 Zob. m.in. А. Шасцюк, Кальвінства, „Беларуская мінуўшчына” 1995, nr 4, s. 62-64; Л. Іванова, Еўрапейскае аблічча і рэгіянальныя асаблівасиі рэфармацыі на Беларусі (другая палова XVI - сярэдзіна XVII cm), Мінск 1998; еаdет, Рэфармацыя ў Польшчы і Вялікім княстве Літоўскім. Сувязі і кантакты, w: Беларусы і палякі: дыялог народаў і культур. X-XX ст., red. Д. Караў, Гродна 1999, s. 54-59; еаdет, Роля Берасцейскай друкарні ў распайсюджванні Рэфармацы у у Вялікім княстве Літойскім, w: Берасиейскія кнігазборы, red. А. Мяснянкіна, Т. Кавенька, Брэст 2010, s. 260-267; еаdeт, Выданне твора „Гісторыя жорсткіх ганенняу Божай иарквы” (Брэст, 1567) у кантэксие тэндэниый рэлігійнай талерантнасиі у ВКЛ, w: Берасиейскія кнігазборы..., s. 271-277; Рэфармацыя і грамадства: ХVI стагоддзе, red. С. Акіньчыц, Мінск 2005.

${ }^{46}$ Zob. m.in. Л. Криштапович, И. Котляров, Брестская церковная уния (прочлое и настоящее), Минск 1996; Гісторыя Беларусі, cz. 1, red. Я. Новік, Г. Марцул, Мінск 1998; Я. Трещенок, ор. сіt.; В. Теплова, Брестский церковный собор и Брестский церковный синод 1596 г. в свете православной экклезиологии, „Studia Historica Europae Orientalis. Исследования по истории Восточной Европы” 2008, t. 1, s. 173-183; Л. Левшун, К вопросу о роли иерковной унии 
historiografię dziejów Kościoła unickiego i jego wpływu na społeczeństwo ruskie (białoruskie), należy zaznaczyć, że w ostatnim czasie pojawiły się nowe oceny unii brzeskiej. Przede wszystkim, badacze zwracają uwagę na istnienie wewnętrznych czynników przy podpisywaniu unii, pokazują rolę i wpływ ideologów unickich na rozwój kultury narodowej, podają w wątpliwość tezę o tym, że Kościół greckokatolicki sprzyjał polonizacji Białorusinów, zaznaczają, że wykorzystanie doświadczenia katolickiego nie przeszkadzało unitom bronić swojej szczególnej pozycji w społeczeństwie. Mamy więc do czynienia, w pewnym sensie, $\mathrm{z}$ legitymizowaniem wkładu Kościoła greckokatolickiego w rozwój białoruskiej kultury narodowej, architektury, sztuki, muzyki, oświaty itd. ${ }^{47}$ Niektórzy badacze uważają unię brzeską za jedną z form przejawiania się idei białoruskiej. Inni przez postrzeganie unityzmu jako swoistego fenomenu próbują pokazać uniwersalność Białorusi, która znajduje się „między Zachodem a Wschodem”. Wydaje się, że dużo zrobiono $\mathrm{w}$ badaniach na temat religii $\mathrm{w}$ Wielkim Księstwie Litewskim, ale na dzień dzisiejszy na Białorusi nie ma żadnej syntezy z historii stosunków konfesyjnych i etnokonfesyjnych, a i nie wszystkie wyznania są dobrze zbadane (np. islam i judaizm). Istnieją luki $\mathrm{w}$ badaniu pewnych zagadnień z zakresu historii kultury Wielkiego Księstwa Litewskiego. Często specjaliści uzasadniają to brakiem źródeł (przede wszystkim z okresu do końca XV w.). Na tle sukcesów w badaniu języka starobiałoruskiego, literatury, piśmiennictwa, sztuki, tradycyjnej kultury ludowej, architektury ${ }^{48}$, brakuje prac na temat systemu edukacji świeckiej

(1596 г.) в формировании белорусской национальной культуры, „Studia Historica Europae Orientalis. Исследования по истории Восточной Европы” 2010, t. 3, s. 245-254; Ф. Кривонос, Православная церковь в Великом княжестве Литовском во второй половине XV-XVI столетиях: на пути к провозглашению Брестской унии, „Труды Минской Духовной академии” 2011, nr 9, s. 59-70; А. Хотеев, Конщепция „золотого века” и Реформация в Беларуси, „Сектоведение" 2011, nr 1, s. 51-64; С. Чернов, Первоисточники о Брестской иерковной унии и актуальность их изучения в наши дни, w: Христианство в Беларуси: история и современность, А. Коваленя, Минск 2014, s. 92-99.

47 Zob. m.in. C. Марозава, Берасцейская унія і этнічная свядомасиь беларусай, „Беларускі гістарычны агляд” 1996, t. 3, nr 2, s. 159-181; еаdет, Уніяцикая царква у культурна-гістарыцным развіциі Беларусі (1596-1839 г2.), Гродна 1996; еадет, Уніяцкая иарква у этнакультурным развіциі Беларусі, 1558-1570, Гродна 2001; еаdет, Берасцейская изаркоўная унія 1596 г. у беларускай гістарыяграфіi, Гродна 2002; еадет, Беларуская гістарыяграбія канфесійнай гісторыі Вялікага княства Літоўскага 1991-2003 г2., w: Вялікае княства Літоўскае: гісторыя вывучэння у 1991-2003 г2., red. С. Каун, Мінск 2006, s. 159-168; С. Падокшын, Унія. Дзяржаўнасиъ. Культура: Філасофска-гістарычны аналіз, Мінск 1998; idem, Inaцій Пацей: иаркоўны дзеяч, мыслічель, пісьменнік на пераломе культурна-гістарычных эпох, Мінск 2001; У. Конан, Беларуская мастацкая культура эпохі Сярэдневякоўя і Рэнесансу, Мінск 2006; idem, Гісторыя эстэтычнай думкі Беларусі, t. 1, Мінск 2010.

${ }^{48}$ Zob. m.in. Анталогія даўняй беларускай літаратуры: XI - пермая палова XVIII cm., red. В. Чамярыцкі, Мінск 2003; Нарысы гісторыі культуры Беларусі: y 4 m., red. А. Лакотка, t. 1-3, Мінск 2013-2014; А. Кушнярэвіч, Культавае дойлідства Беларусі XIII-XVI cmст.: Гістарычнае і архітэктурна-археалагічнае даследаванне, Мінск 1993; Г. Галенчанка, 
i kościelnej ${ }^{49}$, wyjaśnienia roli Cerkwi prawosławnej, Kościoła katolickiego oraz Kościoła ewangelicko-reformowanego ${ }^{50} \mathrm{w}$ procesie kulturalno-historycznym, mentalności, świadomości historycznej i etnicznej Białorusinów. Kontynuuje się dyskusję na temat wyznaczenia cywilizacyjnej orientacji kultury Białorusi i Litwy w kontekście opozycji „Wschód-Zachód”. I tu oceny badaczy zależą od ich pozycji - narodowej czy prorosyjskiej (ostatnia często powiązana $\mathrm{z}$ teorią zachodniorusizmu z XIX w.).

Ważnym czynnikiem $\mathrm{w}$ prowadzeniu badań $\mathrm{z}$ historii Wielkiego Księstwa Litewskiego jest publikacja źródeł. Na Białorusi ukazało się kilka tomów Metryki Litewskiej ${ }^{51}$, testamenty szlachty i mieszczan z II połowy

Франиыск Скарына - беларускі і усхходнеславянскі першадрукар, Мінск 1993; Гісторыя беларускай тітаратуры: Старажытны перыяд, red. М. Лазарук, Мінск 1997; Барока у беларускай культуры і мастацтве, red. В. Шматаў, Мінск 1998; Т. Габрусь, А. Кулагін, М. Ткачоў, Страчаная спадчына, Мінск 1998; А. Лакотка, Начьыянальныя рысы беларускай архітэктуры, Мінск 1999; Л. Левшун, История восточнославянского книжного слова в XIXVII вв., Минск 2001; Т. Габрусь, Мураваныя хараль: Сакральная архітэктура беларускага барока, Мінск 2001; С. Кавалёў, Літаратура Беларусі позняга Рэнесансу: жанры, творы, асобы, Мінск 2005; Л. Клімуць, Сармацкая культура беларускай шляхты, Мінск 2013.

${ }^{49}$ Do tej pory ukazały się m.in. następujące prace: Т. Блинова, Иезуиты в Беларуси: Роль иезуитов в организации образования и просвещения, Гродно 2002; А. Скеп'ян, Роля пратэстаникіх школ у сістэме адукащыі Беларусі ў 16 - першай палове 17 cmст., „Адукацыя і выхаванне” 2000, nr 6, s. 62-66; еаdет, Кальвінісикая гімназія ў Слуцку ў XVII cm., „Беларускі гістарычны часопіс" 2012, nr 2, s. 25-33.

${ }^{50}$ Ostatnio i tu następują zmiany, zob. nр.: И. Рекуц, Протестантизм и художественная культура Беларуси, Минск 1995; А. Скеп'ян, Да пьтання развіция мецэнацтва у Вялікім Княстве Літоўскім у XVI - першай палове XVII cmст., w: Старонкі гісторыі і культуры Беларусі, red. А. Каханоўскі, Мінск 1997, s. 57-71; I. Чарота, Беларуская мова і Царква, Мінск 2000; С. Падокшын, Беларуская думка у кантэксие гісторыі і культуры, Мінск 2003; І. Клімаў, Рэфармацыя у гісторыі літаратурных моў славян, Мінск 2003; І. Бортнік, Праблема талеранцы у праваслаўнай тэалагічнай і сацыяльна-палітычнай думцы Рэчы Паспалітай другой паловы XVI cm., „Иппокрена” 2008, nr 1, s. 83-89; idem, Філасофская i грамадска-палітычная думка Беларусі: вучэбна-метадычны дапаможнік, Наваполацк 2010; Н. Березкина, Культурно-просветительская деятельность Брестской типограбии (1553-1570), w: Берасиейскія кнігазборы..., s. 230-237; Н. Верас, Бібліятэкаметрычны аналіз брэсикага кнігадрукавання у XVI ст., w: Берасиейскія кнігазборы..., s. 246-253; Гісторыя філасофскай і грамадска-палітычнай думкі Беларусі: у 6 т., t. 3: Рэфармацыя. Контррэфармащыя. Барока, Мінск 2013.

${ }^{51}$ Метрыка Вялікага княства Літоўскага. Кніга 28 (1522-1552): копія канца XVI ст., red. В. Мянжынскі, У. Свяжынскі, Менск 2000; Метрыка Вялікага княства Літоўскага. Кніга 44: кніга запісаў 44 (1559-1566), red. А. Груша, Мінск 2001; Перапіс войска Вялікага княства Літоўскага 1528 года. Метрыка Вялікага княства Літоўскага. Кніга 523. Кніга публічных спраў, red. Г. Галенчанка, Мінск 2003; Метрыка Вялікага княства Літоусккага. Кніга 43 (15231560): кніга запісаў 43 (копія канца XVI ст.), орrac. В. Мянжынскі, Мінск 2003; Метрыка Вялікага княства Літоускага. Кніга 46 (1562-1565): кніга запісаў 46 (копія канца XVI cm.), oprac. В. Мянжынскі, Мінск 2006; Метрыка Вялікага княства Літоўскага: кніга $560(1542$ год): кніга перапісаў 3 (копія канца XVI cm.), орrac. А. Дзярновіч, Мінск 2007; Метрыка 
XVI w. ${ }^{52}$, w 1996 r. pojawiła się seria „Białoruś w księgach aktowych XVIXVIII w." ${ }^{53}$, zainicjowano wydawanie wielotomowego herbarza szlachty białoruskiej ${ }^{54}$ oraz rejestrów szlachty w poszczególnych powiatach ${ }^{55}$. Pojawiają się edycje dokumentów w białoruskich czasopismach naukowych ${ }^{56}$.

Analiza współczesnej historiografii białoruskiej pokazuje, że większość badaczy ciągle wykorzystuje neopozytywizm w opisywaniu wydarzeń. Tłumaczone to jest tym, że w historii Białorusi są problemy, głównie faktograficzne, które potrzebują wyjaśnienia „W pierwszej kolejności”. W ostatnim czasie zaczęły pojawiać się prace $\mathrm{z}$ historii codzienności $\mathrm{c}^{57}$, gender studies ${ }^{58}$, urbanistyki ${ }^{59}$, historii mentalności. Nie

Вялікага княства Літоўскага. Кніга 70 (1582-1585): кніга запісаў 70 (копія канца XVI cm.), орrac. А.А. Мяцельскі, Мінск 2008; Метрыка Вялікага княства Літоўскага. Кніга 30 (1480-1546): кніга 30 (копія канцза XVI cm.), орrac. В. Мянжынскі, Мінск 2008; Метрыка Вялікага княства Літоўскага. Кніга 272 (1576-1579): кніга судовых спраў № 58 (копія каниза XVI cm.), орrac. А. Мяцельскі, Мінск 2015; Метрыка Вялікага княства Літоўскага: кніга № 42 (1556-1562): кніга запісаў 42 (копія канца XVI cm.), ортас. В. Мянжынскі, Мінск 2015. Zob. też Г. Галенчанка, Метрыка Вялікага княства Літоўскага: гісторыя, даследаванні, выданні: (кароткі нарыс), Мінск 2014.

52 Тастаменты шляхты і мяшчан Беларусі другой паловы XVI cm. (з актавых кніг Нацыянальнага гістарычнага архіва Беларусі), Мінск 2012.

${ }^{53}$ Магілёўскі магістрат. 1580-1581, 1588, Мінск 1999 („Беларусь у актавых кнігах XVI-XVIII стст., t. 1).

54 Zob. m.in. Mаль гербоўнік Наваградзкай шляхты, red. А. Гануш, А. Леуччык, С. Рыбчонак i in., Мінск 1997; Гербоўнік беларускай шляхтыь, t. 1, red. А. Галубовіч, Мінск 2002; Гербоўнік беларускай шляхты, t. 2b, red. А. Галубовіч, Мінск 2007; Гербоўнік беларускай шляхты, t. 3b, red. А. Рахуба, Мінск 2014; А. Цітоў, Гербоўнік беларускіх гарадоў (XVI - пачатак XX ст.), Мінск 2015.

55 Zob. m.in. Я. Анішчанка, Шляхта Брестского воеводства: список XVIII ст., Минск 2011; idem, Шляхта Слонимского повета: список XVIII cm., Минск 2012; idem, Шляхта Мстиславского повета: список XVIII cm., Минск 2013; idem, Шляхта Мозырского повета: список XVIII cm., Минск 2014; idem, Шляхта Оршанского повета: список XVIII ст., Минск 2015; idem, Шляхта Речицкого повета: список XVIII cm., Минск 2015; А. Залівака, Радаводы шляхецкіх сем'яў ВКЛ на літару „В”. Фасцыкул I, Мінск 2011; іdет, Шляхта Магілёўскай губерні. Спісы. Фасиькул II, Мінск 2012; ideт, Шляхта Магілёускай губерні. Радаводы. Кніга I. Фасиьькул III, Мінск 2014; іdeт, Шляхта Віцебскай губерні. Радаводы. Кніга 2. Фасиьькул V, Мінск 2014.

${ }^{56} \mathrm{~Np}$. „Архіварыўс. Зборнік навукова-папулярных паведамленняў і артыкулаў” 2001-.

57 Zob. m.in. Ю. Бохан, А. Скеп'ян, Побыт феадалаў Вялікага княства Літоўскага ў XV-XVII стагоддзя, Мінск 2011; Н. Алексейчикова, Д. Синицын, Насилие в семьях белорусских горожан в XVI -XVIII веках, „История. Философия. Политика. Право: научные труды преподавателей гуманитарных дисциплин” 2012, t. 2, s. 3-6; Н. Алексейчикова, Преступления в семьях белорусских горожан в XVI-XVIII веках, „История. Философия. Политика. Право: научные труды преподавателей гуманитарных дисциплин” 2014, t. 7, s. 3-7.

${ }^{58}$ Н. Сліж, Статус жанчыны-цляхиянкі у ВКЛ (XVI-XVIII cm.), „Беларускі гістарычны часопіс" 1996, nr 4, s. 57-66; еаdет, Шлюбныя і пазашлюбныя стасункі шляхты Вялікага княства Літоускага, Смаленск 2015; Н. Гардзіенка, Выхаванне шляхиянак у Вялікім княстве Літоўскім у XVIII cm., „Беларускі гістарычны часопіс” 2001, nr 5, s. 26-31; 
można twierdzić, że są one dominujące w dyskursie naukowym, jednak już fakt ich istnienia świadczy o postępie w rozwoju myśli historycznej na Białorusi.

Podsumowując, można stwierdzić, że we współczesnej historiografii białoruskiej Wielkiego Księstwa Litewskiego są zwolennicy tak idei narodowej, jak i oficjalnej - prorosyjskiej i antyzachodniej. Ścieranie się tych dwóch różnych koncepcji w studiach nad dziejami Wielkiego Księstwa Litewskiego najbardziej przejawia się w podręcznikach dla szkół średnich i akademickich. Trudno w tej chwili powiedzieć o wyraźnej dominacji jednej z nich, ponieważ dość często autorzy wykorzystują półtony dla opisywania niektórych wydarzeń.

\section{Streszczenie}

W czasach sowieckich okres istnienia Wielkiego Księstwa Litewskiego uznawano za najgorszy czas w historii Białorusi, ponieważ białoruskie ziemie znajdowały się pod władzą litewskich oraz polskich okupantów. W takiej sytuacji powstała w latach 50 . teoria narodzin narodu staroruskiego stała się dodatkowym argumentem za przyłączeniem ziem białoruskich do Rosji. Na początku lat 90., już w niepodległej Białorusi, powstała „narodowo-państwowa” koncepcja historii, która dawała priorytet wartościom narodowym oraz deklarowała deideologizację i depolityzację historii. Badacze zwrócili uwagę na dobrowolny charakter utworzenia Wielkiego Księstwa Litewskiego, które uznawali za państwo białorusko-litewskie, i przeważnie starali się zajmować jego historią polityczną. Przemiany polityczne połowy lat 90 . odbiły się na ocenach historyków. Jedni próbowali powrócić do koncepcji sowieckiej, inni pozostali na pozycjach narodowych. Najwyraźniej różnicę tę widać w ocenach utworzenia Wielkiego Księstwa Litewskiego, zawarcia unii lubelskiej oraz brzeskiej, polityki zewnętrznej (szczególnie dotyczy to stosunków z państwem moskiewskim). W artykule wskazano także najważniejsze kierunki badań z zakresu historii religii, kultury, historii codzienności, gender studies oraz główne edycje źródłowe do dziejów Wielkiego Księstwa Litewskiego.

еаdет, Кляштарнае выхаванне шляхиянак у Вялікім княстве Літоускім у XVIII cm., „Адукацыя і выхаванне” 2001, nr 4, s. 63-67; еadem, Грамадска-палітычная дзейнасць жанциын шляхецкага саслоўя у Рэчы Паспалітай у XVIII cm., „Terra Historica” 2002, nr 1, s. 24-34; Р. Аляхновіч, Праваздольнасць жанчыны у ВКЛ у ХVI cm. на прыкладзе жыция і дзейнасці „пані Літаворавай”, „Беларускі гістарычны часопіс” 2011, nr 4, s. 22-27; eadem, Материальное обеспечение женщины в ВКЛ второй половины XV - первой половины XVI в.: приданое, „Гістарычна-археалагічны зборнік” 2012, t. 27, s. 32-43; еadem, Пачатак заняпаду „знакомитого” дому: Ян і Ядзвіга Ільінічы, w: Карэліччына: людзі, падзеі, час, red. А. Каваленя, Мінск 2012, s. 73-87; А. Скеп'ян, Жанчыны пры магнацкіх дварах Вялікага княства Літоўскага у XVI-XVII стст., „Гістарычна-археалагічны зборнік” 2014, t. 29, s. $92-102$.

59 А. Бобр, Мой Мозырь: исторический очерк, Минск 1996; I. Марзалюк, Магілёу у ХІІXVIII cmст.: людзі і рэчы, Мінск 1998; Дзевяцзь стагоддзяў Барысава, Мінск 2002; Друик i Барысаў: да юбілеяу старажытных гарадоў: Друик, 1000. Барысаў, 900, Мінск 2002; А. Мяцельскі, Старадаўні Крычаў, Мінск 2003; Д. Дук, Полацк XVI-XVIII стагоддзяў: нарысы тапаграбіi, гісторыі матэрыяльнай культуры і арганізацы жыциёвай прасторы насельніцтва беларускага горада, Наваполацк 2007; Города, местечки и замки Великого княжества Литовского: энииклопедия, red. В. Саламаха, Минск 2009, 2013. 


\section{Belarusian historiography of the Grand Duchy of Lithuania after 1991 \\ Abstract}

During Soviet times the period of the existence of the Grand Duchy of Lithuania was considered the worst in the history of Belarus, as the Belarusian territories were considered to have been under Lithuanian and Polish occupation. A theory from the 1950s, about the origins of the old Russian [sic!] nation, became thus a powerful argument in favor of the unification of the Belarusian territories with Russia. At the beginning of the 1990s the newly independent Belarus witnessed a development of the so-called "national state" conception of history which gave priority to national values and declared an approach to research without ideological and political influences. The historians of that time emphasized "the free will" aspect of the establishment of the Grand Duchy of Lithuania, they considered it as the Belarusian-Lithuanian state and chose mostly research into political history. The political changes in Belarus in the mid-1990s were also reflected in the opinions of the historians. Some of them returned to historical views from Soviet times, others remained on the national historical positions. It is apparent in the evaluations of the founding of the Grand Duchy of Lithuania, the Lublin and Brest Unions, foreign policy - especially relations with the Muscovite state. The article points out to the main directions in research of the history of religion, culture, everyday life, gender relations, as well as major editions of sources to the history of the Grand Duchy of Lithuania.

Lubou Kozik - kandydat nauk historycznych, docent; docent Katedry Historii Słowian Południowych i Zachodnich Białoruskiego Uniwersytetu Państwowego w Mińsku. Jej zainteresowania naukowe koncentrują się wokół historii Polski w XX w., mitów historycznych oraz ich odzwierciedlenia w publikacjach naukowych i akademickich. E-mail: lubov.kozik@gmail.com 